\title{
Comparison of artificial neural networks (ANN), support vector machine (SVM) and gene expression programming (GEP) approaches for predicting TBM penetration rate
}

\author{
Alireza Afradi ${ }^{1}$. Arash Ebrahimabadi ${ }^{1}$
}

Received: 23 June 2020 / Accepted: 27 October 2020 / Published online: 17 November 2020

(c) Springer Nature Switzerland AG 2020

\begin{abstract}
The history of tunnel boring machine (TBM) tunnelling dates back to nearly 50 years ago. Due to high construction cost, the investigation on TBM performance is regarded as one of the crucial issues which should be considered from different aspects. The prediction of TBM penetration rate is one of the most important part of every mechanized tunnelling project which plays a key role in selecting the machine as well. One of the major difficulties and challenges in TBM performance prediction is to apply novel approaches to predict the TBMs penetration rate. Considering the importance of this issue, the objective of this research work is to attain more realistic models for predicting TBM penetration rate in Iranian water conveyance tunneling. With this respect, a database comprises field data and machine parameters in Chamshir water conveyance tunneling project were established. The data were then analyzed through artificial neural networks (ANN), support vector machine (SVM) and gene expression programming (GEP). Results demonstrated that obtained values of the coefficient of determination $\left(R^{2}\right)$ and the root mean square error (RMSE) found to be 0.99 and 0.15 for ANN, 0.95 and 0.37 for SVM, 0.99 and 0.11 for GEP, respectively. These models can be applied to predict TBM penetration rate in the Chamshir water conveyance tunnel. Moreover, it can be concluded that the GEP method has the higher accuracy (maximum $R^{2}$ and minimum RMSE) among all predictive models.
\end{abstract}

Keywords Tunnel boring machine (TBM) · Chamshir water conveyance tunnel · Artificial neural networks (ANN) . Support vector machine $(\mathrm{SVM}) \cdot$ Gene expression programming (GEP)

\section{Introduction}

TBMs are the most outstanding excavating machines in tunnels and underground spaces [1,2]. One of the important tasks in mechanical excavation is to predict the penetration rate (PR) of the miner [3, 4]. Knowing the factors influencing the penetration rate is crucial because it can directly affect project's schedule, particularly cutting time, as well as operating costs $[5,6]$. Penetration rate is the key factor through performance prediction of tunnel boring machines (TBMs) $[7,8]$.
There are various methods and equations to predict PR $[9,10]$, each has its own characteristics $[11,12]$ due to site specific rock mass parameters and machine specifications $[13,14]$. TBMs penetration rate is the first and most important step in predicting the time of tunneling project $[15,16]$. One of the major difficulties and challenges in TBM performance prediction is to find more precise approaches to predict the TBMs penetration rate. Considering the importance of this issue and existing site specific models, the aim of this study is to use modern methods and compare their results to yield more

$\square$ Arash Ebrahimabadi, Arash.xer@gmail.com; A.Ebrahimabadi@Qaemiau.ac.ir|'Department of Mining and Geology, Qaemshahr Branch, Islamic Azad University, Qaemshahr, Iran. 
realistic models for predicting TBM penetration rate in Iranian water conveyance tunneling.

Oraee and Salehi [17] proposed a new model for advance rate in TBMs. Hassanpour et al. [18] calculated TBM performance based on experience of TBM tunneling. Mohammadi et al. [19] suggested the TBM penetration rate using intact and mass rock properties. Paltrinieri et al. [20] studied the analysis and estimation of gripper TBM performances. Salimi et al. [21] developed a model for TBM performance prediction by regression technique. Jakubowski et al. [22] proposed a new model for the tunnel boring machine performance by multivariate linear regression technique. Liu et al. [23] presented a model for TBM performance prediction using a rock mass classification system. Maji and Theja [24] measured TBMs performance for rock. Mikaeil et al. [25] proposed a model to predict the penetration rate by fuzzy technique. Yagiz et al. [26] presented a model for prediction of rock brittleness. Adoko and Yagiz [27] proposed a new model for TBM field penetration index. Namli and Bilgin [28] developed a model to predict daily advance rates of EPB-TBMs. Afradi et al. [29] suggested a new method for TBM penetration rate using ant colony optimization, bee colony optimization and the particle swarm optimization. The aim of this paper is to show the application of ANN, SVM and GEP for prediction of TBM penetration rate in Chamshir water conveyance tunnel which is considered as one the most important TBM tunneling projects in Iran. Furthermore, the capability of these approaches to attain the more realistic results is investigated.

\section{Materials and Methods}

\subsection{The study area}

Chamshir water conveyance tunnel is located in the northwest of Bushehr Province and northeastern part of the city of Dilam and has been implemented to transfer water to Chamshir dam in Kohgiluyeh province in Iran [30]. A comprehensive database is compiled from field data and machine parameters during tunnel construction. It should be stated that theses parameters are the most influential parameters on TBM performance. The list of parameters and the statistical description of the data is presented in Table 1, and Fig. 1 shows the situation of the Chamshir water conveyance tunnel.

\subsection{Artificial neural networks (ANN)}

With the discovery that the human brain performs computations quite differently from conventional digital computers studies on artificial neural networks have grown [31,32]. The brain is a very complicated and parallel structure $[33,34]$. Due to the ability to organize the fundamental elements of neurons, the brain has the capability to perform many calculations (such as pattern recognition, perception, etc.) at a much faster rate than the fastest digital computer [35, 36]. For example, consider the visual process, which in fact is a kind of information processing $[37,38]$. The brain can easily handle the visual perception process at a time of $100-200 \mathrm{~ms}$ $[39,40]$. However, the ability to detect much simpler images for conventional computers is much lower [41, 42]. Another interesting example of the complex brain capabilities is the sound system of the bat $[43,44]$. This system has the ability to provide information such as bat distance to the target [for example, a flying mosquito], as well as relative velocity, dimensions, azimuth and target height $[45,46]$. However, all these very complex calculations occur in the brain rapidly $[47,48]$. Today's most advanced radars are not capable of doing this. At birth, the brain has a huge building and it has the ability to build and develop itself according to what we call "experience." In fact, experience is built up over time, and the highest volume of brain changes occurs during the first 2 years of birth, although this evolution continues

Table 1 Parameters and the statistical description of the database

\begin{tabular}{|c|c|c|c|c|c|c|c|c|c|}
\hline & $\begin{array}{l}\text { Joint } \\
\text { spacing }(m)\end{array}$ & $\begin{array}{l}\text { Joint } \\
\text { angle } \\
\text { (Deg.) }\end{array}$ & $\begin{array}{l}\text { Revolutions } \\
\text { per minute } \\
\text { (RPM) (cycle / } \\
\text { min) }\end{array}$ & $\begin{array}{l}\text { Uniaxial } \\
\text { compressive } \\
\text { strength } \\
\text { (UCS) (MPa) }\end{array}$ & $\begin{array}{l}\text { Poisson's } \\
\text { ratio }\end{array}$ & $\begin{array}{l}\text { Brazilian ten- } \\
\text { sile strength } \\
\text { (BTS) (MPa) }\end{array}$ & $\begin{array}{l}\text { Thrust per } \\
\text { cutter (KN) }\end{array}$ & Power(KW) & $\begin{array}{l}\text { Penetration } \\
\text { rate }(\mathrm{PR}) \\
(\mathrm{m} / \mathrm{h})\end{array}$ \\
\hline Mean & 0.20 & 26.62 & 5.61 & 47.33 & 0.27 & 7.12 & 198.60 & 710.63 & 2.661 \\
\hline $\mathrm{N}$ & 100 & 100 & 100 & 100 & 100 & 100 & 100 & 100 & 100 \\
\hline $\begin{array}{l}\text { Std. Devia- } \\
\text { tion }\end{array}$ & 0.22 & 6.55 & 2.23 & 23.95 & 0.06 & 1.66 & 34.05 & 204.32 & 1.66 \\
\hline Minimum & 0.1 & 19 & 3 & 10 & 0.20 & 5.00 & 150 & 480 & 1.5 \\
\hline Maximum & 1.6 & 50 & 10 & 90 & 0.40 & 10.00 & 250 & 1200 & 9.0 \\
\hline Variance & 0.05 & 42.92 & 5.00 & 573.83 & 0.004 & 2.76 & 1159.47 & $41,748.70$ & 2.77 \\
\hline
\end{tabular}




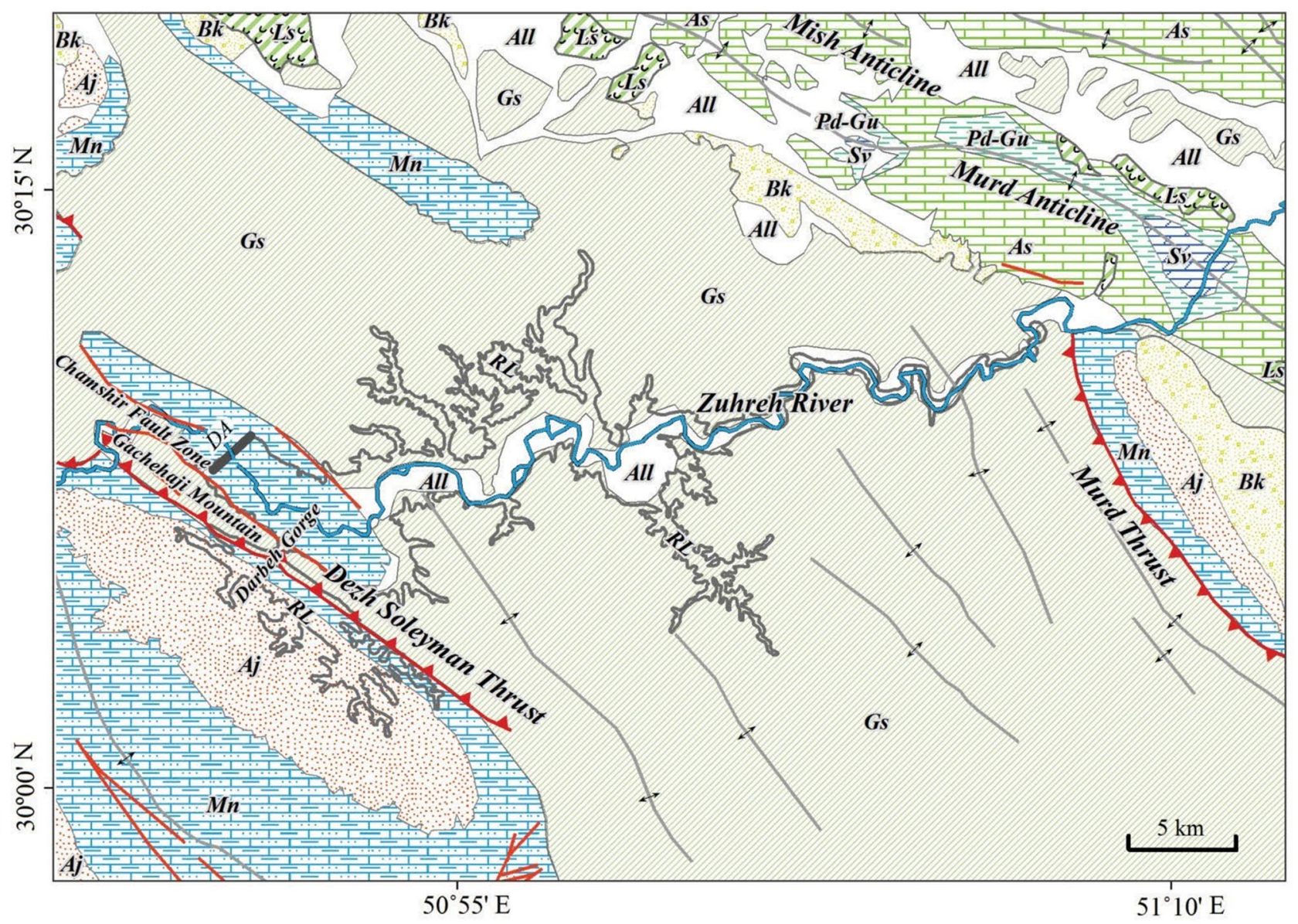

\begin{tabular}{|c|c|c|c|}
\hline \multicolumn{4}{|c|}{ LEGEND } \\
\hline All & Alluvium & Fin & Reservoir Limit \\
\hline Bk & Bakhtiyari Fm. & - & Dam Axis (DA) \\
\hline 4 & Aghajari Fm. & $\uparrow$ & Anticline \\
\hline Mne & Mishan Fm. & $\longrightarrow$ & Fault \\
\hline Gs & Gachsaran Fm. & مــــ & Thrust Fault \\
\hline As & Asmari Fm. & 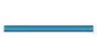 & River \\
\hline Ph- $-G \bar{u}$ & Pabdeh-Gurpi Fm. & & \\
\hline$\frac{S y}{5 y}$ & Sarvak Fm. & & \\
\hline yosects & Landslide & & \\
\hline
\end{tabular}

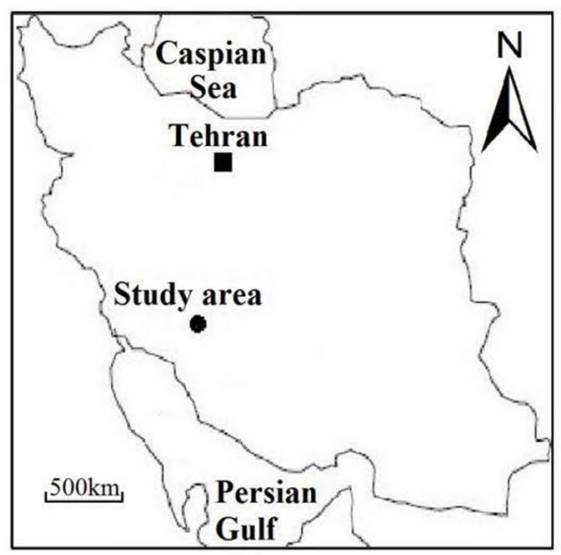

Fig. 1 Location of Chamshir water conveyance tunnel [30]

throughout life $[49,50]$. On the other hand, the plasticity of the brain allows the neurons to adapt to the surrounding environment $[51,52]$. Generally, a neural network is a system designed to model brain function in a specific activity [53]. Neural networks are usually used as software in digital computers [54]. Also, for better performance, 
these networks require a large amount of connections between "neurons" and "processing units" [55]. According to the above explanations, the following definition can be provided for neural networks: a very parallel and distributed neural network that consists of small processor units and has an inherent interest in storing empirical information and preparing it [56]. The neural network is similar to the brain in general:

1. Information is obtained in the same way as the brain through a learning process from the environment.

2. Synaptic weights are used to store information.

The steps are called the learning algorithm, which during this learning process weighs synaptically to correct an optimal response $[57,58]$. The strength and ability of a neural network comes from two factors: first, a very parallel and scattered structure $[59,60]$. The human nervous system is the same as a 3-step system. The first subsystem is the information receiver from the surrounding area $[61,62]$. In the middle of this, brain system is the name of the neural network [63]. This section is constantly receiving information, understanding and decision making [64]. The final operator provides the answer after the decision stages in the final stage of the system $[65,66]$. A neural network (artificial) is a network of simple elements called neurons that receive inputs and modify their internal status according to the same input (activation) and output according to input and activation $[67,68]$. This network connects the output of some of the neurons to the input of other neurons and forms a directional and weighted graph $[69,70]$. Weights, as well as the functions, that compute activation can be modified under a process called learning [71], which is managed by a learning rule [72].

A neuron labeled $j$ that receives input $p_{j}(t)$ from its predecessor neurons consists of the following components [64]:

A. An activator, which depends on a time discrete parameter.

B. Probably a threshold $\theta j$, which is constant unless changed by the learner function.
C. An activation function $\mathrm{f}$ that computes the new activator at given time $t+1$ from $\theta_{j}, a_{j}(t)$, and net $p_{j}$ input and obtains the following Eq. $(1)[65,66]$ :

$$
a_{\mathrm{j}}(t+1)=f\left(a_{\mathrm{j}}(t), p_{\mathrm{j}}(t), \theta_{\mathrm{j}}\right)
$$

And an output function that calculates the output of the activator:

$o_{j}(t)=f_{\text {out }}(a j(t))$

The diffusion function calculates the input of $p_{j}(t)$ to neurons $j$ from the outputs $o_{i}(t)$ of neurons before and is usually as follows $[67,68]$ :

$p_{j}(t)=\sum_{i} o_{j}(t) w_{i j}$

Mathematically, the function $f(x)$ of a neuron network is defined as a combination of other $g_{i}(x)$ functions that can themselves be decomposed into other functions. The following is a summary of $g_{i}$ functions as a vector $[69,70]$ :

$g=\left(g_{1}, g_{2}, \ldots, g_{n}\right)$

This requires defining a cost function $C: F \rightarrow R$ so that for the optimal answer we have $f^{*}[71]$ :

$C\left(f^{*}\right) \leq C(f) \forall f \in F$

As a simple example, consider finding the model $f$, which minimizes $C=E\left[(f(x)-y)^{2}\right]$ for ordered pairs of data $(x, y)$ from a $D$ distribution. In practice, we have only $N$ instances of $D$, so for the above example, we minimize only the following statement [72]:

$\hat{C}=\left(\frac{1}{N} \sum_{i}^{N}\left(f\left(x_{i}\right)-y_{j}^{2}\right)\right)$

ANN structure of Chamshir water conveyance tunnel is shown in Fig. 2. It should be stated that several ANN structure has been made (in terms of different hidden and output layers with different nodes) and simplest structure with the lowest error was selected as ANN structure for Chamshir water conveyance tunnel.
Fig. 2 ANN structure of Chamshir water conveyance tunnel

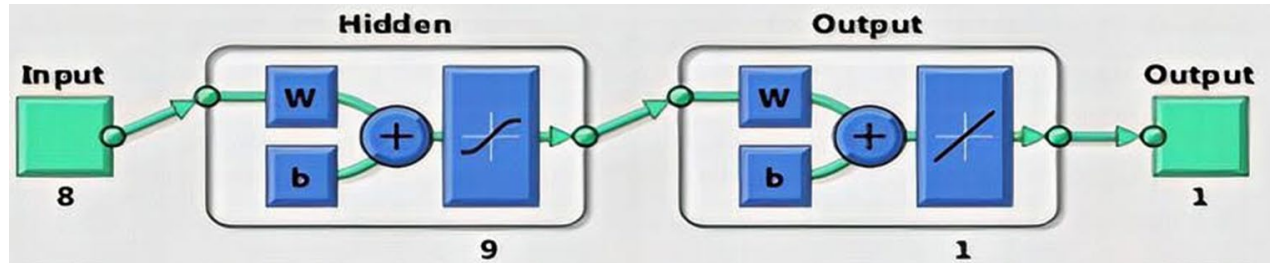




\subsection{Support vector machine (SVM)}

At the beginning of the classification, we examine the data for a case. If the samples are linearly separable, you should look for the best line or super-page that can split the two categories $[73,74]$.

In $w \cdot x+b=0$, the vector $w$ is called the weight, which is perpendicular to the separator superplane, and $b$ is a bias value $[75,76]$. Borders are defined as follows [Eq. (7)]:

$H^{+}: w \cdot x+b=+1$

$H^{-}: w \cdot x+b=-1$

The patterns on these pages have the closest distance to the optimal super-page, which calls the support vector [77]. The region between the two hyperplanes $\mathrm{H}+$ and $\mathrm{H}$ - is called the Margin.

The classification function in the SVM method is as follows [Eq. (8)]:

$f(x)=\operatorname{sign}(w \cdot x+b)$

It is necessary to solve the problem of optimal superconductivity as follows [Eq. (9)]:

Minimize $\frac{\|\boldsymbol{w}\|^{2}}{2}=\frac{1}{2}(w . w)$

Subjectto: $y_{i}(w . x+b) \geq 1 \& y_{i}= \pm 1 \forall i=1,2,3, \ldots, N$

The optimal superconducting objective is apart from all the superscripts that separate the convex corpuscles of the two classes, the best of them is the super-graph, which separates the convex corners of the two classes with the largest margin $[78,79]$. To avoid scaling $w$ and $b$, we conventionally consider the size of the decision function for the closest sample to be equal to 1 as follows [Eq. (10)]:

$\left|\boldsymbol{w} \cdot \boldsymbol{x}_{\boldsymbol{i}}+b\right|=1$

In addition, the distance between each sample is as follows [Eq. (11)]:

$\frac{\left|w \cdot x_{i}+b\right|}{\|\boldsymbol{w}\|}$

In this way, it can be seen the distance of the closest samples from each class is equal $\frac{1}{\|w\|}$ and the width of the margin is equal to $\frac{2}{\|w\|}$ So, we can minimize the value $\frac{\|w\|}{2}$ by maximizing the margin and by placing $\|w\|^{2}$ instead of $\|w\|$ an equation is obtained and its target function. Kernel functions are shown in Table 2 , where $\gamma, d, p$, and $r$ are kernel parameters.

SVM specifications of the Chamshir water conveyance tunnel are shown in Table 3, where $C$ is a positive constant, and $\varepsilon$ is the insensitive zone, both are chosen by the user.
Table 2 Kernel functions

\begin{tabular}{ll}
\hline Linear & $k\left(x_{i} \cdot x_{j}\right)=x_{i}^{T}, x_{j}$ \\
Polynomial & $k\left(x_{i} \cdot x_{j}\right)=\left(\gamma\left\langle x_{i} \cdot x_{j}\right\rangle+r\right)^{d} \gamma>0$ \\
Gaussian & $k\left(x_{i} \cdot x_{j}\right)=\exp \left(-\frac{x_{i}-x_{j}^{2}}{2 p^{2}}\right)$ \\
Radial basis function & $k\left(x_{i} \cdot x_{j}\right)=\exp \left(-\gamma x_{i}-x_{j}^{2}\right) \gamma>0$ \\
Sigmoid & $k\left(x_{i} \cdot x_{j}\right)=\tanh \left(\gamma x_{i} \cdot x_{j}+r\right)$ \\
\hline
\end{tabular}

Table 3 SVM specifications of the Chamshir water conveyance tunnel

\begin{tabular}{clllll}
\hline Model & Kernel & Degree & $\varepsilon$ & $C$ & $\sigma$ \\
\hline$\varepsilon-$ SVR & Radial basis function (RBF) & 2 & 0.1 & 1000 & 0.5 \\
\hline
\end{tabular}

$C$ is also referred to as the regression parameter or penalty parameter and $\delta$ is an independent random noise.

\subsection{Gene expression programming (GEP)}

The program for gene expression was presented by Ferreira [80]. In this program, linear and simple constantlength chromosomes are used in the genetic algorithm and branch structures of different sizes and shapes are combined with expression trees in genetic planning [81]. The first step in the model algorithm is to generate the initial population of solutions, which can be done by random sampling or taking into information about the problem [82]. Chromosomes are expressed as expression tree and evaluated by fit function, if the desired solution or the arrival of generations, the evolution is stopped and the best solution is provided [83, 84]. If the conditions are not stopped, elitist will be done and the remaining solutions will be assigned to the selective process, which will be repeated for several generations and proceeded the generation to a superior quality of the population $[85,86]$. In the planning of gene expression, various operators, such as mutation and combination, are used. The model uses the famous Roulette wheel for selecting individuals $[87,88]$. The mutation operator is a random regeneration within certain chromosomes. The property of this operator to prevent the creation of defective individuals in terms of rules, the operation will run without defects. In this model, a single-point, two-point and gene combination are used. It is preferable that the two-point combination is able to turn the unencoded areas into chromosomes more extensively [89-91]. The general structure of the computation 
performed in the GEP algorithm to arrive at the answer considers the following:

- At first, a generation (first generation) is created (produced).

- The population produced in the community (Hal field) is evaluated.

- The computational problem of the iterations begins to arrive at the answer.

- The next-generation number will be produced.

- The new generation is selected from the previous generation based on the evaluation and evaluation of the traits.

- If the new generation features are not suitable, each new member will be replaced.

- The new population in the community or field of settlement is evaluated.

- The computational loop is repeated long enough to satisfy the condition of generation evolution

Before implementing gene expression programming, consider the following:

1. Set of input variables (fixed numbers)

2. The set of mathematical operators used in the formulas

3. Selection of fit function for formulas fitting

4. Determine the parameters of the program controller (such as population, chromosomes created, etc.)

5. Completion criteria and presentation of program results (Determine a new value for fitting formulas if the fitness level is equal to or greater than that value, stop running.)

Each solution of the population is evaluated by considering Eqs. (12), (13) and (14) and the fitness function is obtained.

if $\left(x=X_{1} \& G(x) \geq 0\right)$

fitness $1(i)=\min |G(x)|$

if $\left(x=X_{1} \& G(x)<0\right)$

fitness2 $(i)=\min |G(x)|$

best_fitness $=\arg \max [$ fitness $1(i)+$ fitness $2(i)]$

In order to create a network for entering primary data for predicting the penetration rate, there is a need for input variables in programming. Genetic programming takes three steps $(A, B, C)$ to solve the problem.
A. Training

Learning is a process in which the network learns how to recognize the pattern in the input. For this purpose, each initial assumption is generated from a set of learning rules defining the mode of learning.

B. Validation

Assessment is the ability of the network to provide acceptable responses to inputs that are not included in the training set.

C. Testing

Implementation is the ability of the network to provide an acceptable answer to the inputs in the training set.

The values of the parameters used in GEP to predict the penetration rate in the Chamshir water conveyance tunnel are shown in Table 4. In Fig. 3, flowchart of GEP algorithm is shown.

\subsection{Evaluation criteria}

In this research, for the purpose of evaluating the accuracy and efficiency of the models, the coefficient of determination $\left(R^{2}\right)$ and root mean square error (RMSE) factors are used according to the following Eqs. (17) and (18).

$R^{2}=\frac{\sum_{i=1}^{N}(X i-\bar{X})(Y i-\bar{Y})}{\sqrt{\sum_{i=1}^{N}(X i-\bar{X})^{2} \sum_{i=1}^{N}(Y i-\bar{Y})^{2}}}$

$\mathrm{RMSE}=\sqrt{\frac{1}{N} \sum_{i=1}^{N}(X i-Y i)^{2}}$

$X i$ and $Y i$ are the computational and observational values of the time step $i, N$ is the number of time steps. $\bar{X}$ and $\bar{Y}$

Table 4 The values of the parameters used in GEP

\begin{tabular}{ll}
\hline Parameter value & Parameter description \\
\hline 10 & (Head size) \\
30 & (Chromosomes) \\
4 & (Number of gene) \\
0.00138 & (Mutation rate) \\
0.1 & (Inversion rate) \\
0.00277 & (One-point recombination rate) \\
0.00277 & (Two-point recombination rat) \\
0.00277 & (Gene recombination rate) \\
0.00546 & (IS transposition rate) \\
0.00546 & (RIS transposition rate) \\
0.00546 & (Gene transposition rate) \\
RMSE & (Fitness Function) \\
$(+)$ & (Linking Function) \\
\hline
\end{tabular}




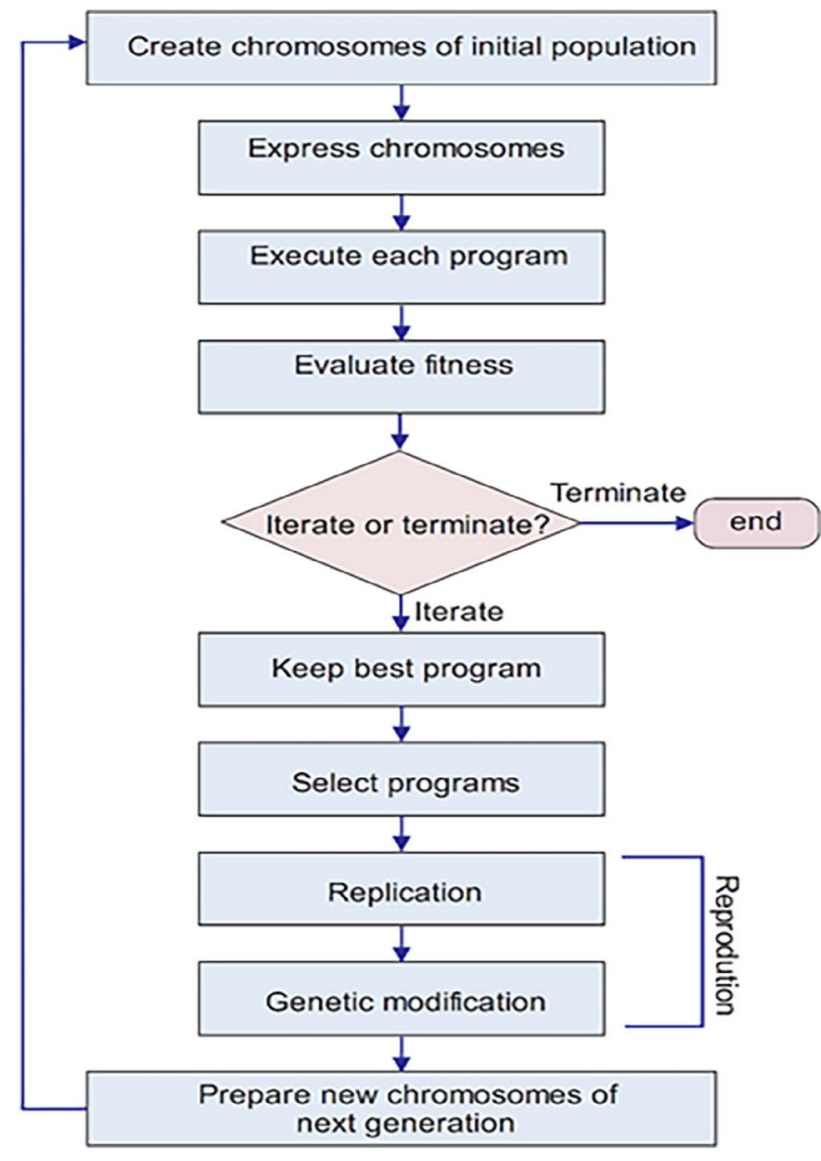

Fig. 3 Flowchart of GEP algorithm [92, 93]

are the average of computational and observational values, respectively.

\subsection{Parameters}

In studies of the main factors influencing penetration rate, we deal with variables that are in some way associated with several other variables. Since the task of science is to predict and explain phenomena, regression analysis can play an important role in research. As a result, to better and more accurately respond to the evaluation of TBM penetration rates in excavating projects, ANN, SVM and GEP be used to establish a relationship between these variables. Input and output parameters used in research are shown in Table 5.

As shown in Table 5, input and output parameters are presented, the penetration rate is considered as the output
Table 5 Input and output parameters

\begin{tabular}{lc}
\hline Input & Output \\
\hline Joint spacing(m), Joint Angle (Deg.), RPM (cycle / min), & $\mathrm{PR}(\mathrm{m} / \mathrm{h})$ \\
UCS(MPa), Poisson's Ratio, BTS(MPa), Thrust Per cutter & \\
(KN), Power (KW) & \\
\hline
\end{tabular}

parameter and joint spacing $(\mathrm{m})$, joint angle (Deg.), RPM (cycle/min), UCS (MPa), Poisson's Ratio, BTS (MPa), Thrust Per Cutter (KN) and Power (KW) were considered as input parameters. In order to evaluate the effect of each variable on increasing or decreasing the penetration rate and establishing a meaningful relationship between them, the steps are entered into the software and each of the variables is added to the regression analysis to create a new model, respectively.

\section{Results of modeling}

\subsection{Modeling results using ANN}

At this point, we evaluate the performance of the network. You can see the results obtained from the network and the best performance of the network in Figs. 4 and 5, respectively. The distribution diagram and the fitting diagram of penetration rates by the predictive model are shown in Figs. 6 and 7, respectively.

\subsection{Modeling results using support vector machine (SVM)}

At this point, using the data in prediction of the TBM penetration rate, we perform modeling using SVM and examine the results. $R^{2}$ and RMSE of the support vector machine model (SVM) are presented in Fig. 8 for predicting the penetration rate of the TBM. The fitting model of PR by SVM is shown in Fig. 9.

\subsection{Modeling results using gene expression programming (GEP)}

At this point, using the data in prediction of the TBM penetration rate, we perform modeling using GEP and examine the results. $R^{2}$ and RMSE of the GEP model for predicting 
Fig. 4 Results obtained from artificial neural network

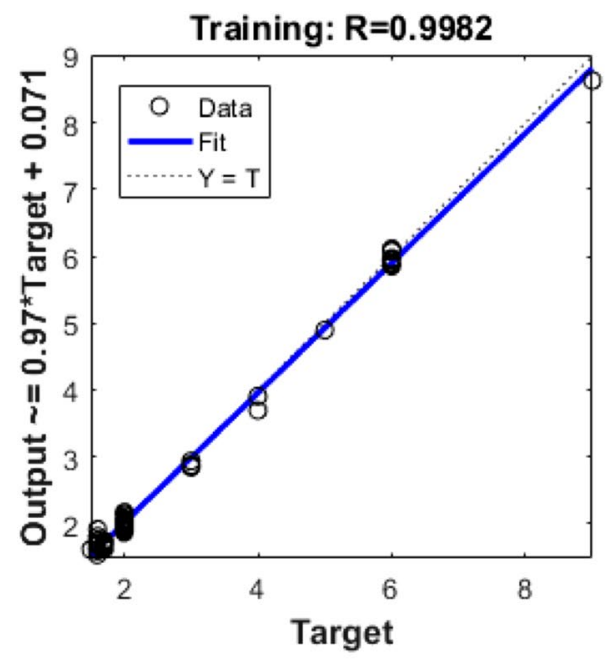

Test: $\mathbf{R}=\mathbf{0} .99211$

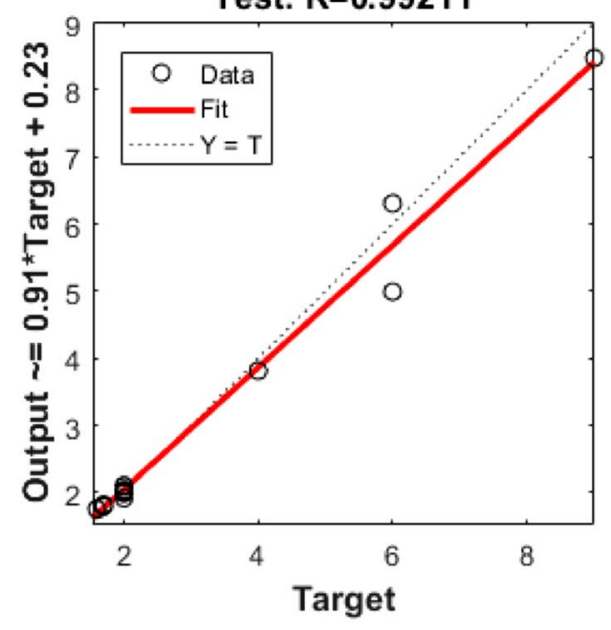

Validation: $\mathbf{R}=0.99298$

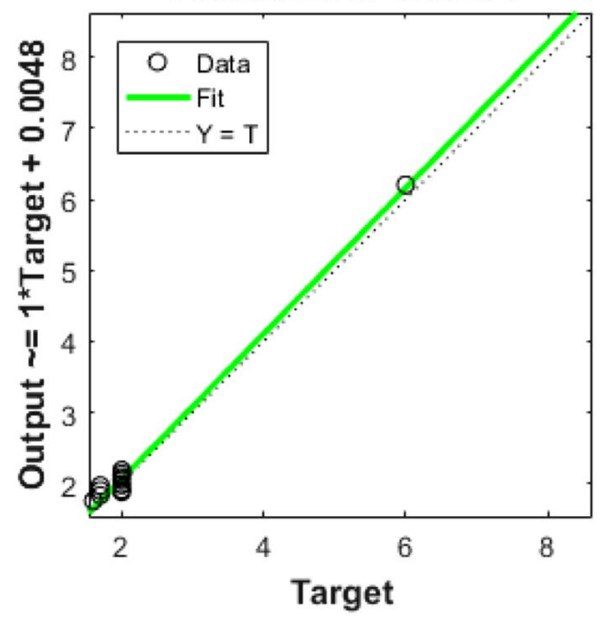

All: $\mathbf{R}=0.99587$

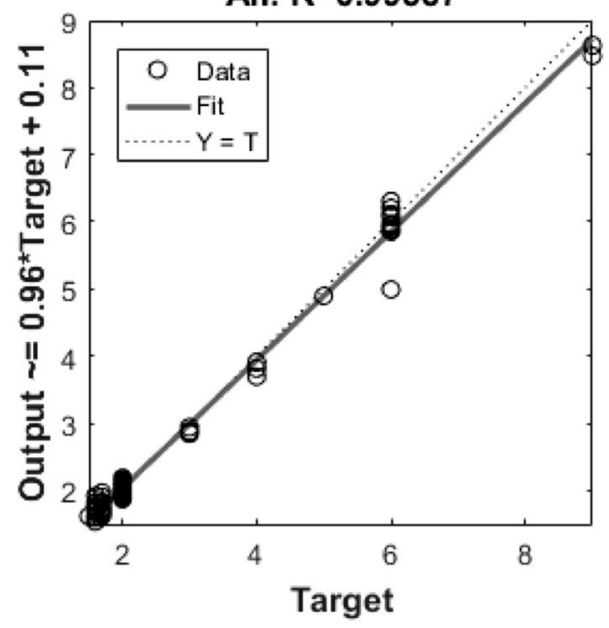

Fig. 5 Best network performance using artificial neural network

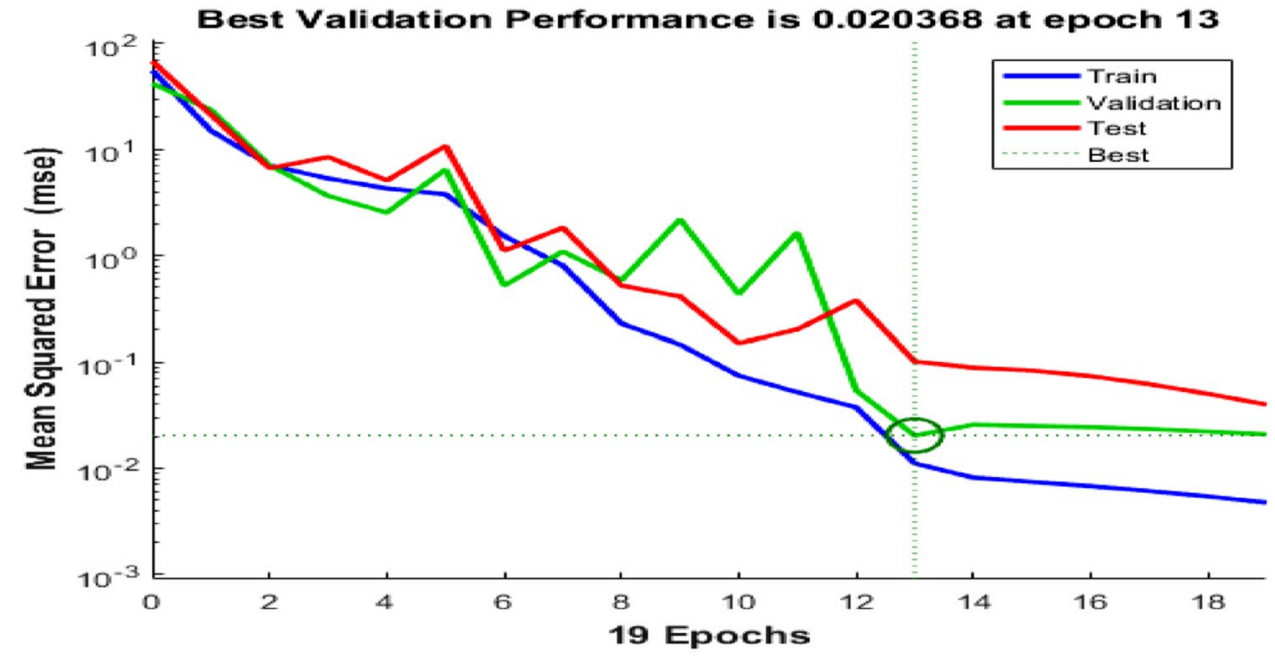




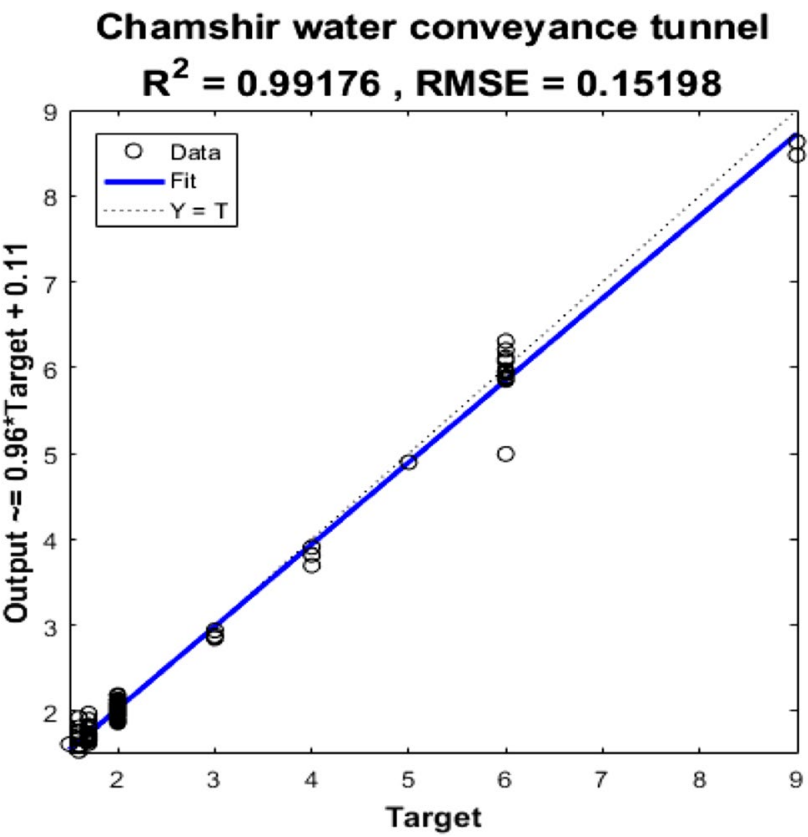

Fig. 6 Distribution diagram of penetration rate by ANN

the TBM penetration rate are shown in Fig. 10. The fitting diagram of PR by GEP in Fig. 11 is displayed. Expression Tree of predictive relation of the penetration rate in this database, created by the GEP model, is shown between input variables and penetration rates in Fig. 12. The

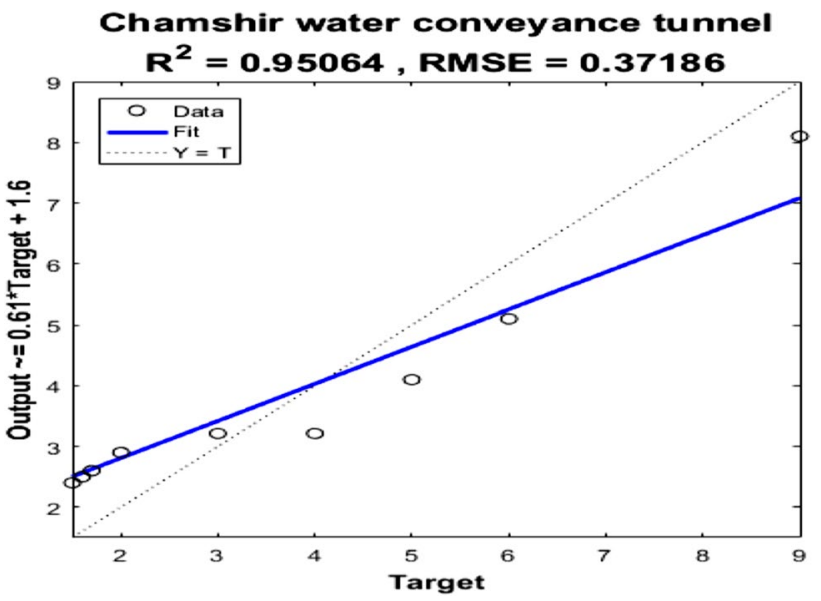

Fig. 8 Distribution diagram of penetration rate by SVM

mathematical expression of this equation is also described in relation to [(Eq. (19)].

$$
\begin{aligned}
\text { ET1 }= & -3.01-\ln (\text { RPM })+0.230-\ln (\text { thrustpercutter })^{2} \\
\text { ET2 }= & 8.87-\frac{1}{(\text { RPM }-6.38)^{3}-2.2} \\
\text { ET3 }= & \ln (\mathrm{UCS}-\mathrm{RPM}-\text { Thrustpercutter } \\
& - \text { Power }+4.21)+\frac{1}{\text { Thrustpercutter }}
\end{aligned}
$$

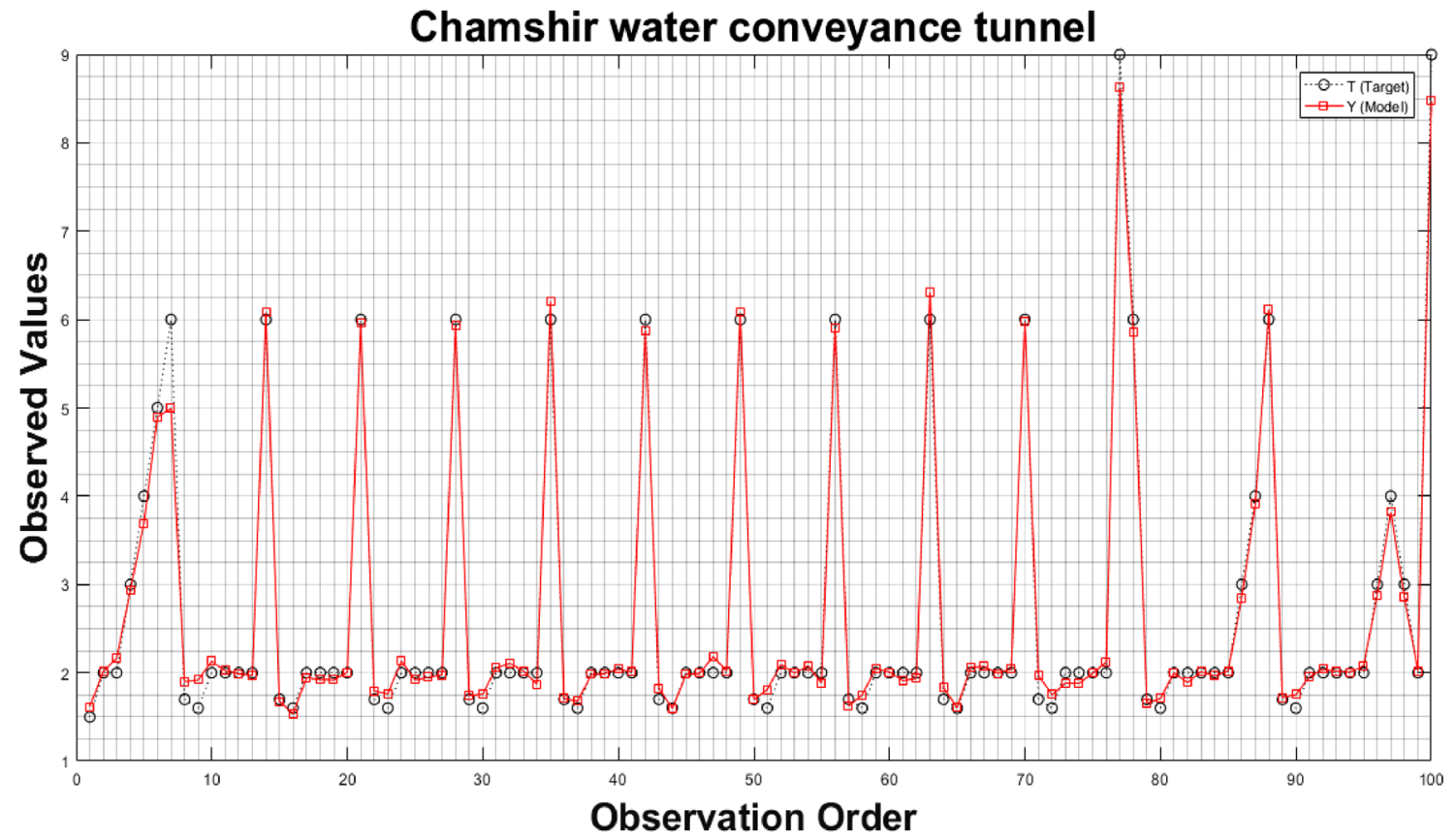

Fig. 7 Fitting diagram of penetration rate by ANN 


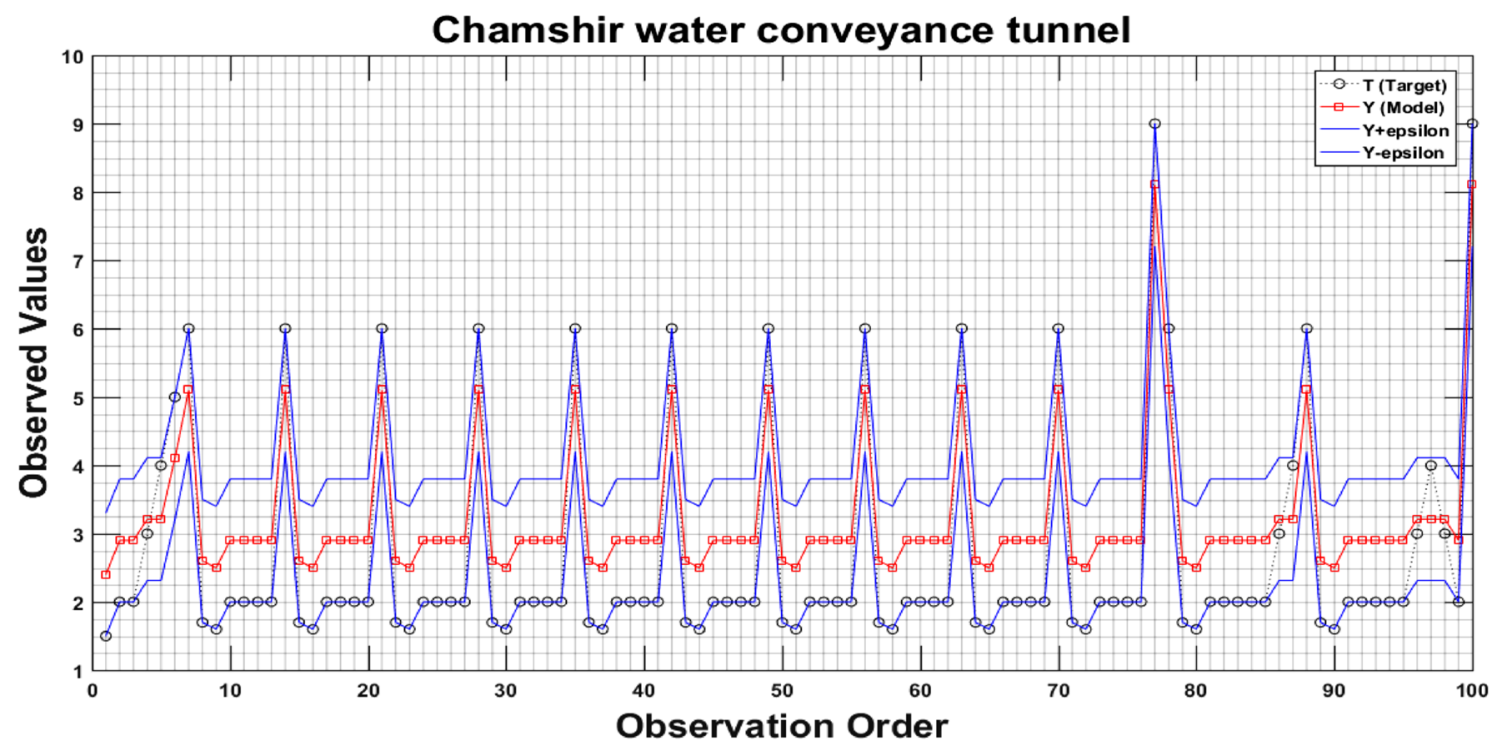

Fig. 9 Fitting diagram of penetration rate by SVM

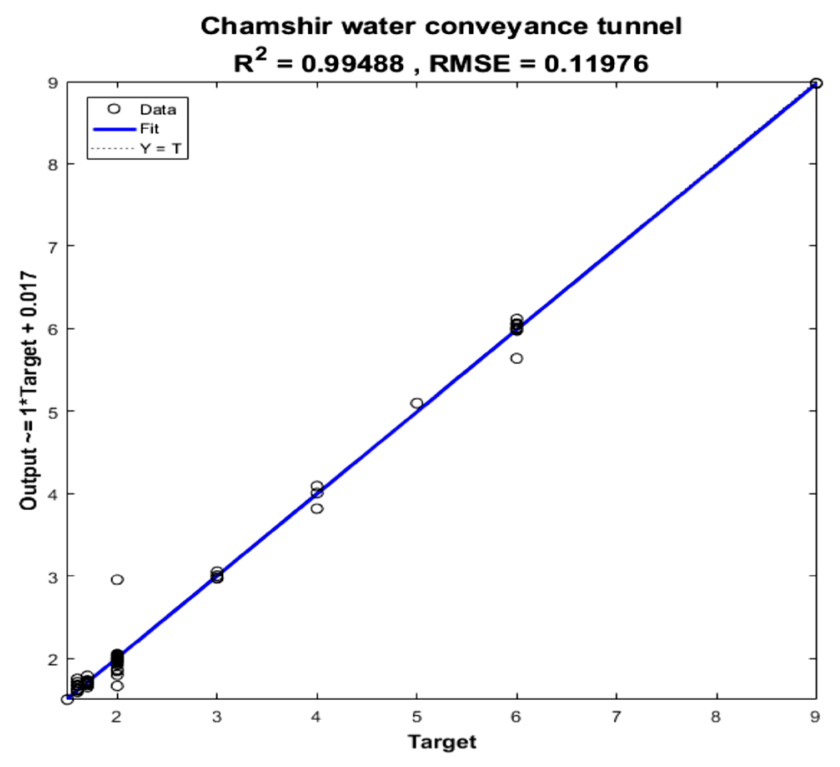

Fig. 10 Distribution diagram of the penetration rate by GEP

\subsection{Comparison of the results}

In this study, a database primarily established from machine parameters and field data for predicting PR in
Chamshir water conveyance tunneling project. With this regard, artificial neural networks (ANN), support vector machine (SVM) and gene expression programming (GEP) applied to the database. The results for predicting PR, as can be seen in Table 6 and Fig. 13. Based on Table 6 and Fig. 13, it can be concluded that all predictive models lead to acceptable results while GEP contributes to a more precise and realistic outcome with higher $R^{2}$ and lower values of RMSE. The results of sensitivity analysis of input parameters are given in Fig. 14. UCS is the most influential parameter in modeling, as can be seen in Fig. 14.

\section{Discussion}

As cited before, mechanized tunneling has many advantages; hence, it is important to predict TBMs performance which is directly related to the prediction of TBM penetration rate. In recent years, many models have been proposed for predicting penetration rate. The aim of this research works is to find more precise predictive models using novel predictive approaches. Among modern techniques, ANN, SVM and GEP are more powerful approaches that are capable to result in more realistic findings in prediction process. Therefore, the authors tried to apply these methods for prediction of TBM performance. Another aspect of using these techniques is to compare the results 


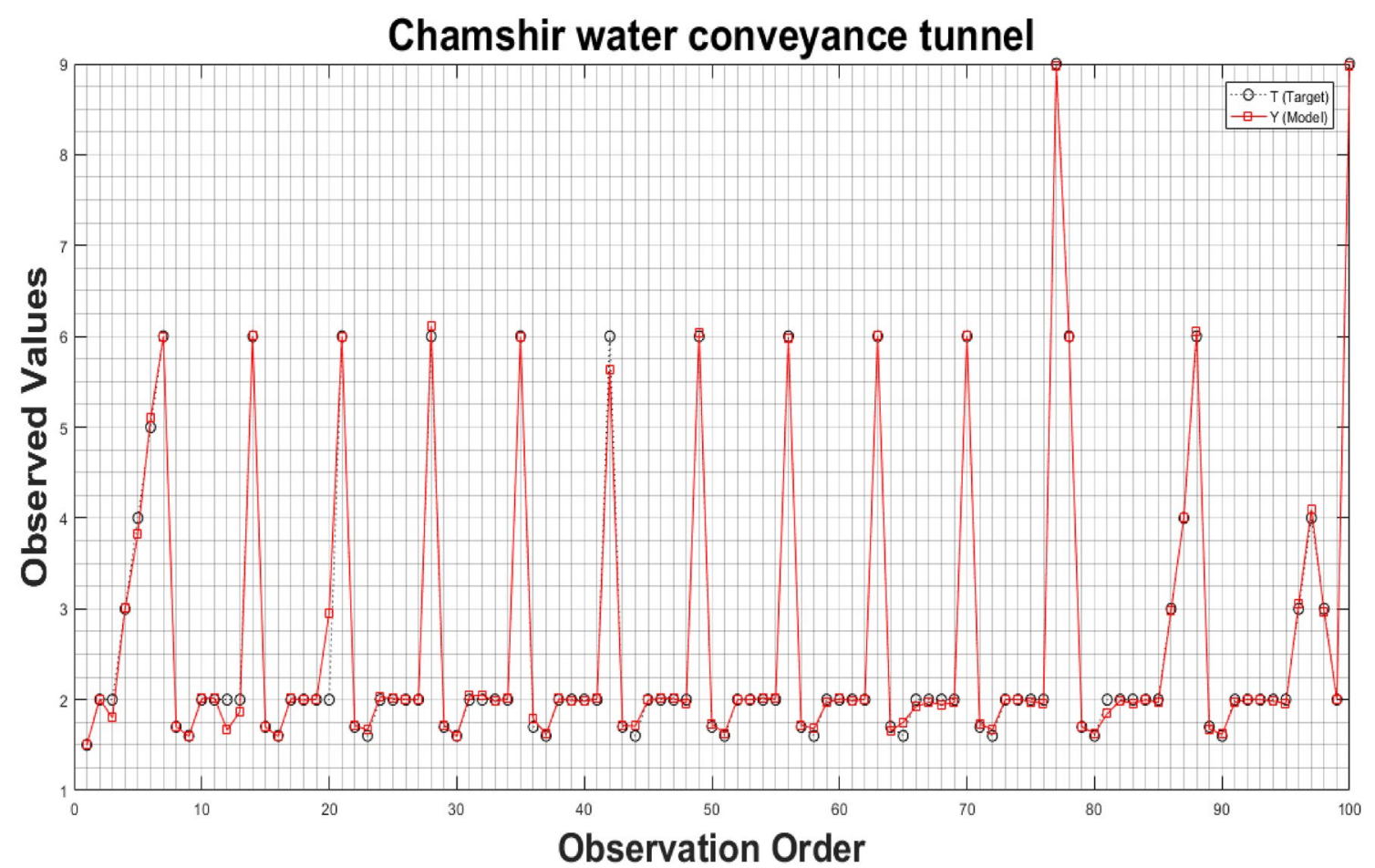

Fig. 11 Fitting diagram of penetration rate by GEP

of this work, Chamshir water conveyance tunneling project as one the most important TBM tunneling projects in Iran, with other water conveyance tunneling projects inside and outside of Iran. Table 7 shows the analogy of the suggested model and the existing ones in terms of the TBM penetration rate. As it can be seen in Table 7, the model presented in this study has the highest $R^{2}$ and the lowest RMSE, which shows a tangible advantage over other models.

\section{Conclusions}

Penetration rate prediction is one of the important indicators of the performance of TBMs. In this study, primarily a database was provided from field data and machine parameters during excavation of Chamshir water conveyance tunnel in Iran. Parameters including joint spacing, Joint Angle, RPM, UCS, Poisson's ratio, BTS, thrust per cutter and power (KW) considered as input parameters and
Penetration Rate (PR) as output parameter through the analyses. The data were then analyzed through artificial neural networks (ANN), support vector machine (SVM) and gene expression programming (GEP). Results demonstrated that obtained values of $R^{2}$ and RMSE found to be 0.99 and 0.15 for ANN, 0.95 and 0.37 for SVM, 0.99 and 0.11 for GEP, respectively. These models are reliable to be applied to predict TBM penetration rate in the Chamshir water conveyance tunnel. Moreover, it can be concluded that the GEP method has the higher accuracy (maximum $R^{2}$ and minimum RMSE) among all predictive models. Gathering additional data such as number of consumed disc cutters could be considered a limitation for such study. For future works, it is suggested to use other novel heuristic algorithms such as shark smell optimization and shuffled frog leaping algorithm to predict the penetration rate of the tunnel boring machine. 

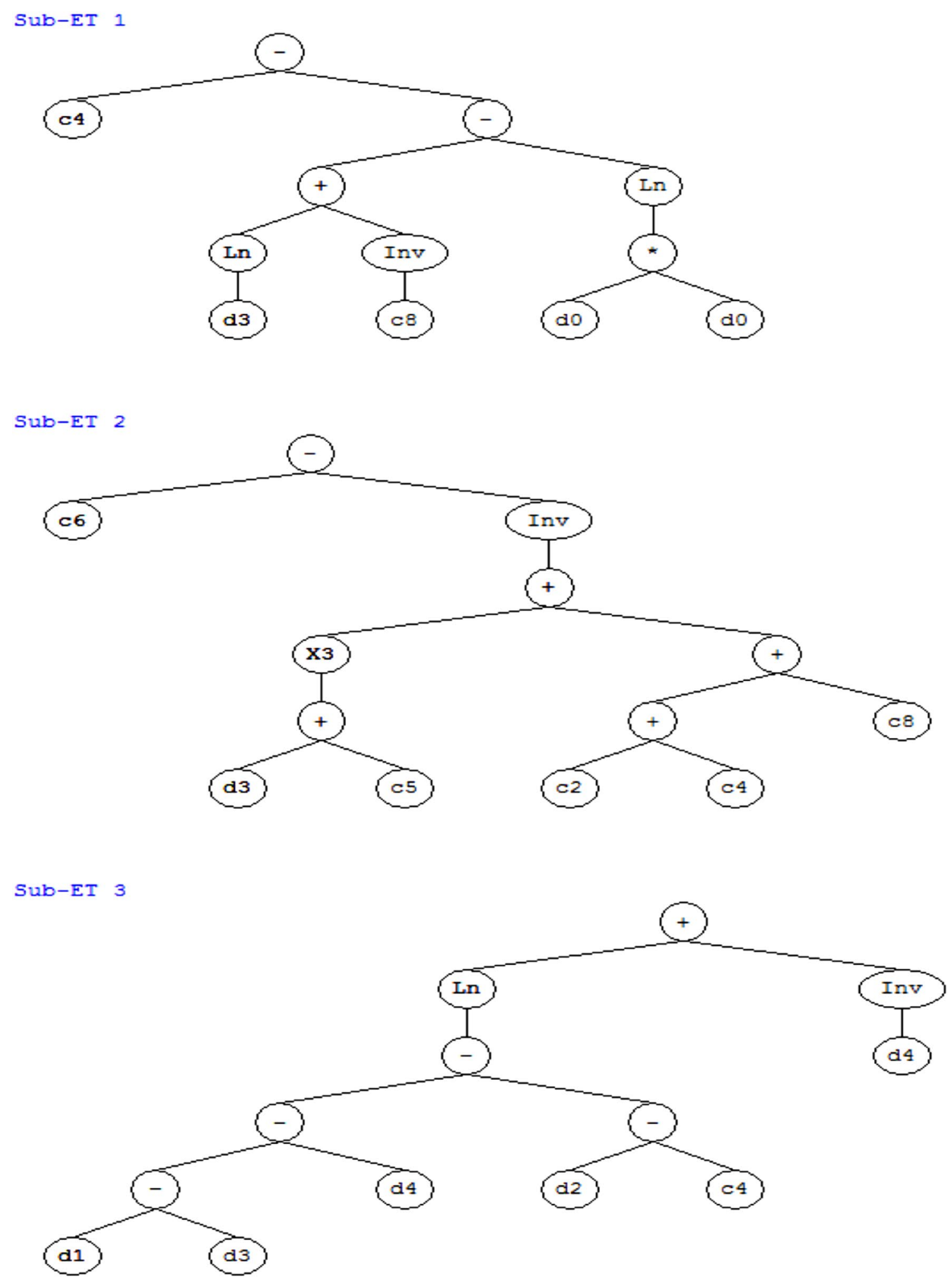

Fig. 12 Expression tree of predictive relation of the penetration rate 
Table 6 Results for predicting PR

Fig. 13 Results of $R^{2}$ and RMSE

Fig. 14 Sensitivity analysis of input parameters

\begin{tabular}{lll}
\hline Model & $R^{2}$ & RMSE \\
\hline ANN & 0.99 & 0.15 \\
SVM & 0.95 & 0.37 \\
GEP & 0.99 & 0.11 \\
\hline
\end{tabular}
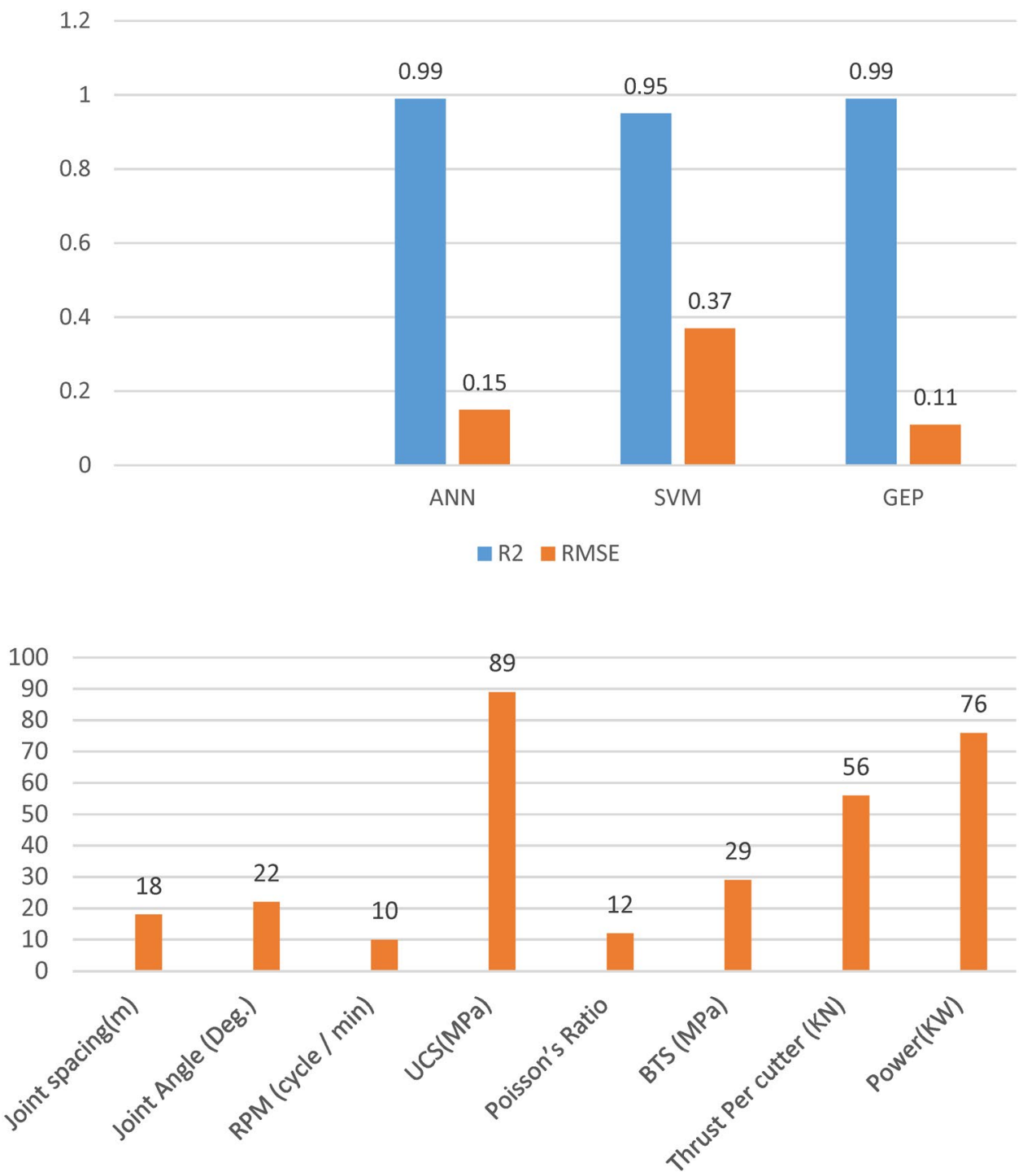

Percentage(\%)

Table 7 The analogy of the suggested model and the existing ones in terms of the TBM penetration rate

\begin{tabular}{lllll}
\hline Model & Output & $R^{2}$ & RMSE & Case Study \\
\hline (This study) & TBM penetration rate $(\mathrm{m} / \mathrm{h})$ & 0.99 & 0.11 & Chamshir water conveyance tunnel \\
Zare Naghadehi et al. [93] & TBM penetration rate $(\mathrm{m} / \mathrm{h})$ & 0.72 & 0.18 & Queens water tunnel \\
Yagiz and Karahan [14] & TBM penetration rate $(\mathrm{m} / \mathrm{h})$ & 0.66 & 0.20 & Queens water tunnel \\
Afradi et al. [91] & TBM penetration rate $(\mathrm{m} / \mathrm{h})$ & 0.97 & 0.48 & Beheshtabad water conveyance tunnel \\
Adoko et al. [1] & TBM penetration rate $(\mathrm{m} / \mathrm{h})$ & 0.66 & 0.22 & Queens water tunnel \\
Afradi et al. [29] & TBM penetration rate $(\mathrm{m} / \mathrm{h})$ & 0.97 & 0.34 & Sabzkooh water conveyance tunnel \\
\hline
\end{tabular}




\section{References}

1. Adoko AC, Gokceoglu C, Yagiz S (2017) Bayesian prediction of TBM penetration rate in rock mass. Eng Geol 226:245-256. https ://doi.org/10.1016/j.enggeo.2017.06.014

2. Ahangari K, Moeinossadat SR, Behnia D (2015) Estimation of tunnelling-induced settlement by modern intelligent methods. Soils Found 55(4):737-748. https://doi.org/10.1016/j.sandf 2015.06 .006

3. Armaghani DJ, Mohamad ET, Narayanasamy MS, Narita N, Yagiz S (2017) Development of hybrid intelligent models for predicting TBM penetration rate in hard rock condition. Tunn Undergr Space Technol 63:29-43. https://doi.org/10.1016/j. tust.2016.12.009

4. Ates U, Bilgin N, Copur $\mathrm{H}$ (2014) Estimating torque, thrust and other design parameters of different type TBMs with some criticism to TBMs used in Turkish tunneling projects. Tunn Undergr Space Technol 40:46-63. https://doi.org/10.1016/J. TUST.2013.09.004

5. Beheshti Aval SB, Ketabdari H, Asil Gharebaghi S (2017) Estimating shear strength of short rectangular reinforced concrete columns using nonlinear regression and gene expression programming. Structures 12:13-23. https://doi.org/10.1016/j.istru c.2017.07.002

6. Benato A, Oreste $P$ (2015) Prediction of penetration per revolution in TBM tunneling as a function of intact rock and rock mass characteristics. Int J Rock Mech Min Sci 74:119-127. https://doi. org/10.1016/j.jirmms.2014.12.007

7. Copur H, Aydin H, Bilgin N, Balci C, Tumac D, Dayanc C (2014) Predicting performance of EPB TBMs by using a stochastic model implemented into a deterministic model. Tunn Undergr Space Technol 42:1-14. https://doi.org/10.1016/J.TUST.2014.01.006

8. Delisio A, Zhao J (2014) A new model for TBM performance prediction in blocky rock conditions. Tunn Undergr Space Technol 43:440-452. https://doi.org/10.1016/j.tust.2014.06.004

9. Delisio A, Zhao J, Einstein HH (2013) Analysis and prediction of TBM performance in blocky rock conditions at the Lötschberg Base Tunnel. Tunn Undergr Space Technol 33:131-142. https:// doi.org/10.1016/j.tust.2012.06.015

10. Frough O, Torabi SR (2013) An application of rock engineering systems for estimating TBM downtimes. Eng Geol 157:112-123. https://doi.org/10.1016/j.enggeo.2013.02.003

11. Ghasemi E, Yagiz S, Ataei M (2014) Predicting penetration rate of hard rock tunnel boring machine using fuzzy logic. Bull Eng Geol Environ 73(1):23-35. https://doi.org/10.1007/s1006 4-013-0497-0

12. Hassanpour J, Ghaedi Vanani AA, Rostami J, Cheshomi A (2016) Evaluation of common TBM performance prediction models based on field data from the second lot of Zagros water conveyance tunnel (ZWCT2). Tunn Undergr Space Technol 52:147-156. https://doi.org/10.1016/j.tust.2015.12.006

13. Yagiz $S$ (2017) New equations for predicting the field penetration index of tunnel boring machines in fractured rock mass. Arabian J Geosci 10(2):33. https://doi.org/10.1007/s1251 7-016-2811-1

14. Yagiz S, Karahan H (2011) Prediction of hard rock TBM penetration rate using particle swarm optimization. Int J Rock Mech Min Sci 48(3):427-433. https://doi.org/10.1016/j.jjrmms.2011.02.013

15. Yagiz S, Karahan H (2015) Application of various optimization techniques and comparison of their performances for predicting TBM penetration rate in rock mass. Int J Rock Mech Min Sci 80:308-315. https://doi.org/10.1016/j.ijrmms.2015.09.019

16. Jalali SME, Zare Naghadehi M (2013) Development of a new laboratory apparatus for the examination of the rotary-percussive penetration in tunnel boring machines. Tunn Undergr Space Technol 33:88-97. https://doi.org/10.1016/j.tust.2012.10.002

17. Oraee K, Salehi B (2013) Assessing prediction models of advance rate in tunnel boring machines-a case study in Iran. Arab J Geosci 6(2):481-489. https://doi.org/10.1007/s12517-011-0339-y

18. Hassanpour J, Rostami J, Zhao J, Tarigh Azali S (2015) TBM performance and disc cutter wear prediction based on ten years experience of TBM tunnelling in Iran. Geomech Tunn 8(3):239247. https://doi.org/10.1002/geot.201500005

19. Mohammadi SD, Torabi-Kaveh M, Bayati M (2015) Prediction of TBM penetration rate using intact and mass rock properties (case study: Zagros long tunnel, Iran). Arab J Geosci 8(6):38933904. https://doi.org/10.1007/s12517-014-1465-0

20. Paltrinieri E, Sandrone F, Zhao J (2016) Analysis and estimation of gripper TBM performances in highly fractured and faulted rocks. Tunn Undergr Space Technol 52:44-61. https://doi. org/10.1016/j.tust.2015.11.017

21. Salimi A, Faradonbeh RS, Monjezi M, Moormann C (2016) TBM performance estimation using a classification and regression tree (CART) technique. Bull Eng Geol Environ. https://doi. org/10.1007/s10064-016-0969-0

22. Jakubowski J, Stypulkowski JB, Bernardeau FG (2017) Multivariate linear regression and CART regression analysis of TBM performance at Abu Hamour phase-I tunnel. Arch Min Sci 62(4):825-841. https://doi.org/10.1515/amsc-2017-0057

23. Liu Q, Liu J, Pan Y, Kong X, Hong K (2017) A case study of TBM performance prediction using a Chinese rock mass classification system - Hydropower Classification (HC) method. Tunn Undergr Space Technol 65:140-154. https://doi.org/10.1016/J. TUST.2017.03.002

24. Maji VB, Theja GV (2017) A New Performance Prediction Model for Rock TBMs. Indian Geotech J 47(3):364-372. https://doi. org/10.1007/s40098-017-0226-x

25. Mikaeil R, Zare Naghadehi M, Ghadernejad S (2017) An extended multifactorial fuzzy prediction of hard rock TBM penetrability. Geotech Geol Eng. https://doi.org/10.1007/S10706-017-0432-4

26. Yagiz S, Ghasemi E, Adoko AC (2018) Prediction of Rock Brittleness Using Genetic Algorithm and Particle Swarm Optimization Techniques. Geotech Geol Eng 36:3767-3777. https://doi. org/10.1007/s10706-018-0570-3

27. Adoko AC, Yagiz S (2019) Fuzzy inference system-based for TBM field penetration index estimation in rock mass. Geotech Geol Eng 37:1533-1553. https://doi.org/10.1007/s10706-018-0706-5

28. Namli M, Bilgin N (2017) A model to predict daily advance rates of EPB-TBMs in a complex geology in Istanbul. Tunn Undergr Space Technol 62:43-52. https://doi.org/10.1016/j. tust.2016.11.008

29. Afradi A, Ebrahimabadi A, Hallajian T (2020) Prediction of tunnel boring machine penetration rate using ant colony optimization, bee colony optimization and the particle swarm optimization, case study: Sabzkooh water conveyance tunnel. Mining Mineral Deposits 14(2):75-84. https://doi.org/10.33271/minin g14.02.075

30. Nikkhah M, Mousavi S, Zare SH, Khademhosseini O (2017) Evaluation of structural analysis of tunnel segmental lining using beam-spring method and force-method (case study: chamshir water conveyance tunnel). JME 8(1):111-130. https://doi. org/10.22044/jme.2016.573

31. Benardos PG, Vosniakos GC (2002) Prediction of surface roughness in CNC face milling using neural networks and Taguchi's design of experiments. Robot Comput Integr Manuf. https://doi. org/10.1016/S0736-5845(02)00005-4

32. Kara F, Aslantas K, Çicek A (2015) Prediction of cutting temperature in orthogonal machining of AISI 316L using artificial neural network. Appl Soft Comput 38:64-74. https://doi.org/10.1016/j. asoc.2015.09.034 
33. Hanief M, Wani MF (2015) Modeling and prediction of surface roughness for running-in wear using Gauss-Newton algorithm and ANN. Appl Surf Sci 357:1573-1577. https://doi. org/10.1016/j.apsusc.2015.10.052

34. Patel KA, Brahmbhatt PK (2016) A comparative study of the RSM and ANN models for predicting surface roughness in roller burnishing. Proc Technol 23:391-397. https://doi.org/10.1016/j. protcy.2016.03.042

35. Kumar R, Chauhan S (2015) Study on surface roughness measurement for turning of $\mathrm{Al} 7075 / 10 / \mathrm{SiCp}$ and $\mathrm{Al} 7075$ hybrid composites by using response surface methodology (RSM) and artificial neural networking (ANN). Measurement 65:166-180. https://doi.org/10.1016/j.measurement.2015.01.003

36. Aydogmus $Z$, Aydogmus $O$ (2015) A comparison of artificial neural network and extended Kalman filter based sensorless speed estimation. Measurement 63:152-158. https://doi.org/10.1016/j. measurement.2014.12.010

37. Unal M, Onat M, Demetgul M, Kucuk H (2014) Fault diagnosis of rolling bearings using a genetic algorithm optimized neural network. Measurement 28:187-196. https://doi.org/10.1016/j. measurement.2014.08.041

38. Shahin MA, Jaksa MB, Maier HR (2001) Artificial neural network application in geotechnical engineering. Aust Geomech 36:49-62

39. Shahin MA (2014) A review of artificial intelligence applications in shallow foundations. Int J Geotech Eng. https://doi. org/10.1179/1939787914Y.0000000058

40. Teh C, Wong KS, Goh ATC et al (1997) Prediction of pile capacity using neural networks. J Comput Civil Eng 11:129-138. https:// doi.org/10.1061/(ASCE)0887-3801(1997)11:2(129)

41. Goh ATC (1995) Back-propagation neural networks for modeling complex systems. Artif Intel Eng 9:143-151. https://doi. org/10.1016/0954-1810(94)00011-S

42. Goh AT (1996) Pile driving records reanalyzed using neural networks. J Geotech Eng 122:492-495. https://doi.org/10.1061/ (ASCE)0733-9410(1996)122:6(492)

43. Pal M, Deswal $S$ (2008) Modeling pile capacity using support vector machines and generalized regression neural network. J Geotech Geoenviron Eng 134:1021-1024

44. Benali A, Nechnech A (2011) Prediction of the pile capacity in purely coherent soils using the approach of the artificial neural networks,Innovat. Valorat. Civ Eng Construct Mater Marocco, pp 23-25

45. Soleimanbeigi A, Hataf N (2006) Prediction of settlement of shallow foundations on reinforced soils using neural networks. Geosynth Int 13:161-170. https://doi.org/10.1680/ gein.2006.13.4.161

46. Padmini D, llamparuthi K, Sudheer K (2008) Ultimate bearing capacityprediction of shallow foundations on cohesionless soils using neurofuzzy models. Comput Geotech 35:33-46. https:// doi.org/10.1016/j.compgeo.2007.03.001

47. Kiefa MA (1998) General regression neural networks for driven piles in cohesionless soils. J Geotech Geoenviron Eng 194:1177-1185. https://doi.org/10.1061/ (ASCE)1090-0241(1998)124:12(1177)

48. Shahin M, Jaksa MB (2009) Intelligent computing for predicting axial capacity of drilled shafts, ASCE geotechnical special publications, international foundation congress and equipment expo (IFCEE'09),Florida, Orlando. pp 26-33. DOI: https://doi. org/10.1061/41022(336)4

49. Jianbin Z, Jiewen T, Yongqiang S (2010) An ANN model for predicting level ultimate bearing capacity of PHC Pipe Pile, Gangbing Song, RameshB. Malla. Earth and Space, pp. 3168-3176

50. Bornholdt S, Graudenz D (1992) General asymmetric neural networks and structure design by genetic algorithms.
Neural Networks 5:327-334. https://doi.org/10.1016/S0893 -6080(05)80030-9

51. Vonk E, Jain LC, Johnson RP (1995) Automatic generation of a neural network architecture using evolutionary computation, In electronic technology directions to the Year 2000, Proceedings. IEEE.DOI: https://doi.org/10.1109/ETD.1995.403479

52. Saemi M, Ahmadi M, Varjani AY (2007) Design of neural networks using genetic algorithm for the permeability estimation of the reservoir. J Petrol Sci Eng 59:97-105. https://doi.org/10.1016/j. petrol.2007.03.007

53. Garrett J (1994) Where and why artificial neural networks are applicable in civil engineering. J Comput Civil Eng 8:129-130. https://doi.org/10.1061/(ASCE)0887-3801(1994)8:2(129)

54. Simpson P (1990) Artificial neural system: foundation, paradigms, applications and implementations. Pergamon, New York, p 1990

55. Dreyfus G (2005) Neural networks: methodology and application, Springer, Berlin Heidelberg DOI: 10.1007/3-540-28847-3

56. Holland J (1975) Adaptation in natural and artificial systems. The University of Michigan Press, Ann Arbor

57. Jadav K, Panchal M (2012) Optimizing weights of artificial neural networks using genetic algorithms. Int J Adv Res Comput Sci Electronics Eng 1:47-51

58. Nazir R, Momeni E (2013) Prediction of axial bearing capacity of spread foundations in cohesionless soils using artificial neural network, in:Proc. GEOCON 2013, the 9th International Conference on Geotechnic and Transportation, October 2013, pp. 747-757

59. Hagan MT, Menhaj MB (1994) Training feed forward networks with the Marquardt algorithm. IEEE Trans Neural Networks 5:861-867. https://doi.org/10.1109/72.329697

60. Martin TH, Howard BD, Mark B (1995) Neural Network Design. PWS Publishing Company, Boston, MA

61. Yang Y, Zang O (1997) A hierarchical analysis for rock engineering using artificial neural networks. Rock Mech Rock Eng 30:207-222. https://doi.org/10.1007/BF01045717

62. Shamshirband S et al (2019) A survey of deep learning techniques: application in wind and solar energy resources,". IEEE Access 7:164650-164666

63. Najafi B (2018) Application of ANNs, ANFIS and RSM to estimating and optimizing the parameters that affect the yield and cost of biodiesel production. Eng Appl Comput Fluid Mech 12:611-624

64. Baghban A et al (2019) Developing an ANFIS based swarm concept model for estimating relative viscosity of nanofluids. Eng Appl Comput Fluid Mech 13:26-39

65. Ardabili SF et al (2018) Computational intelligence approach for modeling hydrogen production: a review. Eng Appl Comput Fluid Mech 12:438-458

66. Taormina R et al (2015) ANN-based interval forecasting of streamflow discharges using the LUBE method and MOFIPS. Eng Appl Artif Intell 45:429-440

67. Wu CL et al (2013) Prediction of rainfall time series using modular soft computing methods. Eng Appl Artif Intell 26:997-1007

68. Lee Y, Oh SH, Kim MW (1991) The effect of initial weights on premature saturation in back-propagation learning, In: Proceedings of the international joint conference on neural networks.DOI: https://doi.org/10.1109/IJCNN.1991.155275

69. Ting Xiang L, Shu Wen Z, Quan Yuan W et al (2012) Research of agricultural land classification and evaluation based on genetic algorithm optimized neural network model, In: Software Engineering and Knowledge Engineering: Theory and Practice, pp. 465-471. Springer, Berlin. Doi: https://doi.org/10.1007/978-3642-25349-2_62

70. Majdi A, Beiki M (2010) Evolving neural network using a genetic algorithm for predicting the deformation modulus of 
rock masses. Int J Rock Mech Min Sci 47:246-253. https://doi. org/10.1016/j.jjrmms.2009.09.011

71. Rashidian V, Hassanlourad M (2013) Predicting the shear behavior of cemented and uncemented carbonate sands using a genetic algorithm-based artificial neural network. Geotech Geol Eng 2:1-18. https://doi.org/10.1007/s10706-013-9646-2

72. Salimi A, Rostami J, Moormann C, Delisio A (2016) Application of non-linear regres-sion analysis and artificial intelligence algorithms for performance prediction of hard rock TBMs. Tunn Undergr Space Technol 58:236-246. https://doi.org/10.1016/j. tust.2016.05.009

73. Gao L, Li X (2015) Utilizing partial least square and support vector machine for TBM penetration rate prediction in hard rock conditions. J Central South Univ 22(1):290-295. https://doi. org/10.1007/s11771-015-2520-z

74. Mahdevari S, Shahriar K, Yagiz S, Akbarpour Shirazi M (2014) A support vector regression model for predicting tunnel boring machine penetration rates. Int J Rock Mech Min Sci 72:214-229. https://doi.org/10.1016/j.ijrmms.2014.09.012

75. Muralidharan V, Sugumaran V, Indira V (2014) Fault diagnosis of monoblock centrifugal pump using SVM. Eng Sci Technol Int J 17(3):152-157. https://doi.org/10.1016/j.jestch.2014.04.005

76. Mohammad Taghi ST et al (2017) Cavitation intensity monitoring in an axial flow pump based on vibration signals using multiclass support vector machine. Proc Inst Mech Eng Part C J Mech Eng Sci. https://doi.org/10.1177/0954406217729416

77. Azadeh A et al (2013) A flexible algorithm for fault diagnosis in a centrifugal pump with corrupted data and noise based on ANN and support vector machine withhyper-parameters optimization. Appl Soft Comput 13(3):1478-1485. https://doi. org/10.1016/j.asoc.2012.06.020

78. Widodo A, Yang BS (2007) Support vector machine in machine condition monitoring and fault diagnosis. Mech Syst Signal Proces 21(6):2560-2574. https://doi.org/10.1016/j.ymssp .2006 .12 .007

79. Gangsar P, Tiwari R (2014) Multiclass fault taxonomy in rolling bearings at interpolated and extrapolated speeds based on time domain vibration data by SVM Algorithms. J Failure Anal Prevention 14(6):826-837. https://doi.org/10.1007/s11668-014-9893-4

80. Ferreira C (2001) Gene expression programming: a new adaptive algorithm for solving problems. Complex Syst 13(2):87-129

81. Ferreira C ( 20040 Gene expression programming and the evolution of computerprograms, In: Castro LND, Zuben FJV (eds) Recent developments in biologically inspired computing, $\mathrm{pp}$ 82-103

82. Dindarloo SR, Siami-Irdemoosa E (2015) Estimating the unconfined compressive strength of carbonate rocks using gene expression programming. Eur J Sci Res 135(3):309-316
83. Ebtehaj I, Bonakdari H, Zaji AH, Azimi H, Sharifi A (2015) Gene expression pro-gramming to predict the discharge coefficient in rectangular side weirs. Appl Soft Comput 35:618-628. https ://doi.org/10.1016/j.asoc.2015.07.003

84. Güllü H (2012) Prediction of peak ground acceleration by genetic expression program-ming and regression: a comparison using likelihood-based measure. Eng Geol 141-142:92-113. https://doi.org/10.1016/j.enggeo.2012.05.010

85. Güllü H (2014) Function finding via genetic expression programming for strength and elastic properties of clay treated with bottom ash. Eng Appl Artif Intell 35:143-157. https://doi. org/10.1016/j.engappai.2014.06.020

86. Keshavarz A, Mehramiri M (2015) New gene expression programming models for normalized shear modulus and damping ratio of sands. Eng Appl Artif Intell 45:464-472. https://doi. org/10.1016/j.engappai.2015.07.022

87. Khandelwal M, Armaghani DJ, Faradonbeh RS, Ranjith PG, Ghoraba S (2016) A new model based on gene expression programming to estimate air flow in a single rock joint. Environ Earth Sci 75(9):739. https://doi.org/10.1007/s12665-016-5524-6

88. Liu J, Yan K, You L, Liu P, Yan K (2016) Prediction models of mixtures' dynamic modulus using gene expression programming. Int J Pavement Eng. https://doi.org/10.1080/10298 436.2016.1138113

89. Ozbek A, Unsal M, Dikec A (2013) Estimating uniaxial compressive strength of rocks using genetic expression programming. J Rock Mech Geotech Eng 5(4):325-329. https://doi.org/10.1016/j. jrmge.2013.05.006

90. Saridemir M (2014) Effect of specimen size and shape on compressive strength of con-crete containing fly ash: application of genetic programming for design. Mater Des 56:297-304. https ://doi.org/10.1016/j.matdes.2013.10.073

91. Afradi A, Ebrahimabadi A, Hallajian T (2019) Prediction of the penetration rate and number of consumed disc cutters of tunnel boring machines (TBMs) using artificial neural network (ANN) and support vector machine (SVM)-case study: Beheshtabad water conveyance tunnel in Iran. Asian J water Environ Pollut 16(1):49-57. https://doi.org/10.3233/ajw190006

92. Ferreira C (2006) Gene expression programming: mathematical modeling by an artificial intelligence, vol 2. Springer-Verlag, Berlin

93. ZareNaghadehi M et al (2018) State-of-the-art predictive modeling of TBM performance in changing geological conditions through gene expression programming. Measurement 126:4657. https://doi.org/10.1016/j.measurement.2018.05.049

Publisher's Note Springer Nature remains neutral with regard to jurisdictional claims in published maps and institutional affiliations. 